\title{
Exploring Historical and Projection of Drought Periods in Cirebon Regency, Indonesia
}

\author{
Nila Ardhyarini H. Pratiwi ${ }^{1, *}$, Mahawan Karuniasa ${ }^{1}$, and Djoko Santoso Abi Suroso ${ }^{2}$ \\ ${ }^{1}$ School of Environmental Science, Universitas Indonesia, Indonesia \\ ${ }^{2}$ School of Architecture, Planning and Policy Development, Bandung Institute of Technology, \\ Indonesia
}

\begin{abstract}
Climate hazards that affect drought could have an impact on agricultural production. Cirebon Regency as one of West Java's food supply areahas experienced hydrological drought because ofclimate variability. Hence, there were many rice fieldswhich lack of water sources for irrigation and resulted in crop failure. Accordingly, this study aims to explore the historical and projection of drought periods as well as the severity of droughts in Cirebon Regency, Indonesia. Interpretation of weather and climate data and Standardized Precipitation Index (SPI) were employed for methods of this studyby using rainfall data only. Based on baseline data (1986-2017) from Jatiwangi Meteorological Stationand Global Circulation Model (GCM) projection simulation (2020-2045) under the Representative Concentration Pathways (RCP) 4.5 scenario, the SPI analysis results show that the drought periodsare predicted to shift in the future with increasing drought severity. This study concludes that climate variability that affects future dry rainfall will still happen in uncertain month periods. Therefore, climatic information is needed in the vulnerable area to reduce the potential impactsthat will occur in the future.
\end{abstract}

\section{Introduction}

The future climate will depend on global warming caused by past and future anthropogenic emissions and natural climate variability [1]. Climate variability can affect extreme dry rainfall and drought which resulting environmental, economic and social impacts in the affected areas. The El Nino event followed by a decrease in rainfall can also lead to longer dry seasons and drought [2-4]. In the tropics, such as Indonesia, El Nino causes climate variability and affects seasonal shifts due to decreased rainfall $[3,5]$.

Drought is characterized by below normal rainfall for several months to years [6]. Drought is projected by many studies as one of the most devastating natural disasters and is becoming more severe and widespread due to climate change and variability [7]. Drought is a consequence of a natural reduction in the amount of rainfall over a long period of time, usually one season or longer, although other climatic factors (such as high temperatures,

\footnotetext{
*Corresponding author: nila.ahp@gmail.com
} 
high winds, and relatively low humidity) are often linked in many regions of the world and can significantly worsen the severity of the event [8].

Drought can be classified into four types [9]. First, a meteorological drought that occurs during under normal rainfall in an area for a certain period of time [6, 10]. Second, agricultural drought usually refers to a period with a decrease in soil moisture and resulting crop failure due to the lack of surface water sources [10]. Third, hydrological drought is associated with the effects of reduced rainfallperiods on surface water supply or subsurface (such as streams, reservoirs, lakes, and groundwater) [8]. Fourth, socio-economic drought is associated with the failure of the water resources system to meet water demand and thereby linking meteorological, hydrological and agricultural drought elements to the supply and demand of economic goods $[8,10]$.

Cirebon Regency is one of the drought-prone areas in Indonesia. Based on Vulnerability Index Data Information System, the drought risk of Cirebon Regency is at moderate level [11]. Drought Hazard Map from the National Agency for Disaster Management also shows that Cirebon Regency has a medium threat to drought with $99 \%$ of the total agriculture land is threatened by drought which could affect up to 185.075 farmers [12]. In 2015, drought affected rice fields to dry due to lack of water supply and caused crop failurein the western part of Cirebon coastal area[13]. Thus, Cirebon Regency is vulnerable to hydrological drought when long dry season. Regarding to that, this study aims to explore the historical and projection of drought periods as well as the severity of droughts in Cirebon Regency, Indonesia. This results could be an alert to the agricultural activities in the study area.

\section{Materials and Methods}

Interpretation of climate data and Standardized Precipitation Index (SPI) were employed for this study as methods. Interpretation of climate data is indispensable in this study to analyze historical rainfall. We used rainfall data as a climate baseline with 32 years timeframe for the period of 1986-2017. In addition, interpretation of climate data was also used to analyze climate projection with aduration of 26 years for the period of 2020-2045. The climate projection data for this study obtained from the Global Circulation Model (GCM)that is a numerical model which represents physical processes in atmosphere, ocean, cryosphere and soil surface.

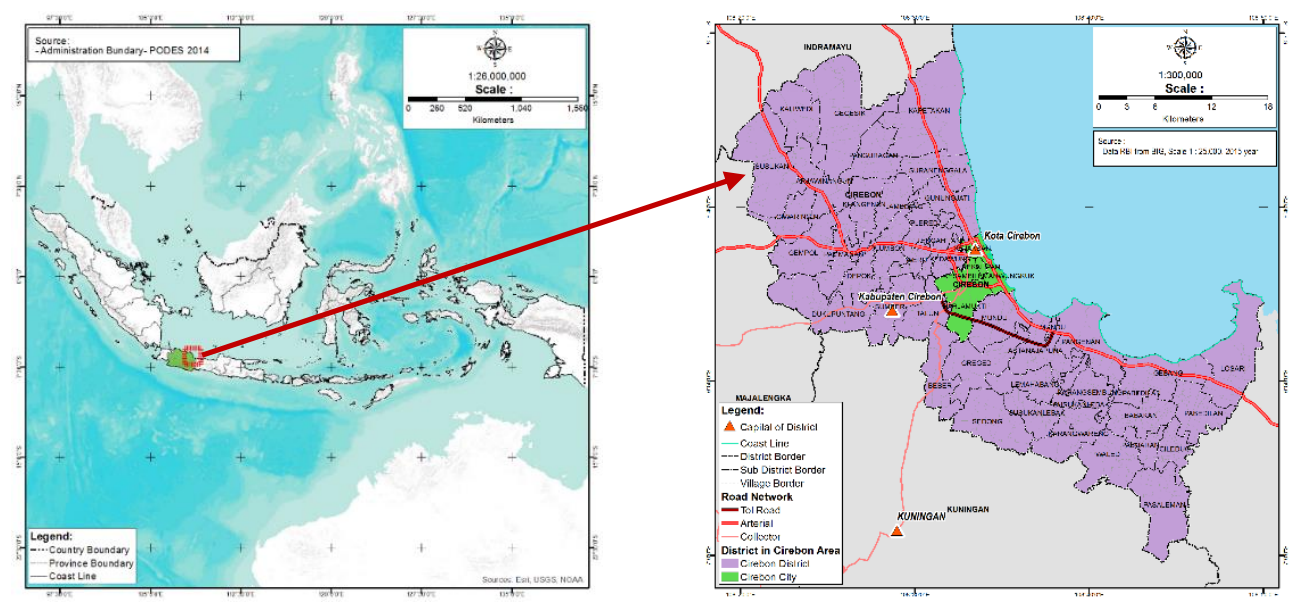

Fig. 1. Study Area 
The SPI method in this study was employed to assess the drought index in Cirebon Regency by using historical data of rainfall for the period of 1986-2017 and projected dataof rainfall for the period of 2020-2045. Various indices for drought analysis based on one or more climate variables have been developed. Nevertheless, the World Meteorological Organization (WMO) has proposed the SPI as the most common standard drought monitoring index because it has simple calculations and flexibility in the use of time periods $[14,15]$. SPI is the number of standard deviations that observed the cumulative precipitation deviates from the climatological average [16]. SPI Program was utilized for this study to compute drought periods as well as the severity of droughts. This tool was developed by The National Drought Mitigation Center, University of Nebraska-Lincoln, and was officially recommended at Lincoln Declaration on Drought Indices in 2011 to be used by all countries and institutions [17].

Table 1. SPI Values

\begin{tabular}{|c|c|}
\hline SPI Values & Classification \\
\hline $2.00+$ & extremely wet \\
\hline 1.50 to 1.99 & very wet \\
\hline 1.00 to 1.49 & moderately wet \\
\hline-0.99 to 0.99 & near normal \\
\hline-1.00 to -1.49 & moderately dry \\
\hline-1.50 to -1.99 & severely dry \\
\hline$-2,00$ and less & extremely dry \\
\hline
\end{tabular}

Source: McKee, 1993

\section{Results and Discussions}

\subsection{Rainfall Historical Trend}

The observation data of study area rainfall from Jatiwangi Meteorological Station in the baseline period of 1986-2017 tends to decrease in April-September and increase in October-March. The lowest rainfall has occurred in August and the highest rainfall has occurred in January. The rainfall trend in Cirebon Regency in the baseline period tends to decrease (see Figure 2). The average annual rainfall in the baseline period is 2.666 .4 $\mathrm{mm} /$ year with average monthly rainfall is $222.2 \mathrm{~mm} / \mathrm{month}$. The highest rainfall occurred in 1989 with a total rainfall of $3.519 .0 \mathrm{~mm}$ and an average rainfall of $293.3 \mathrm{~mm} / \mathrm{month}$. The lowest rainfall occurred in 1997 with the amount of rainfall of $1701.9 \mathrm{~mm}$ and average rainfall of $141.8 \mathrm{~mm} / \mathrm{month}$. In 1997, there has been a strong El Nino and has had major impacts in some parts of the world, such as droughts in the Pacific islands, the Philippines and Indonesia, affecting agricultural output, water supply and hydroelectric power [18]. 


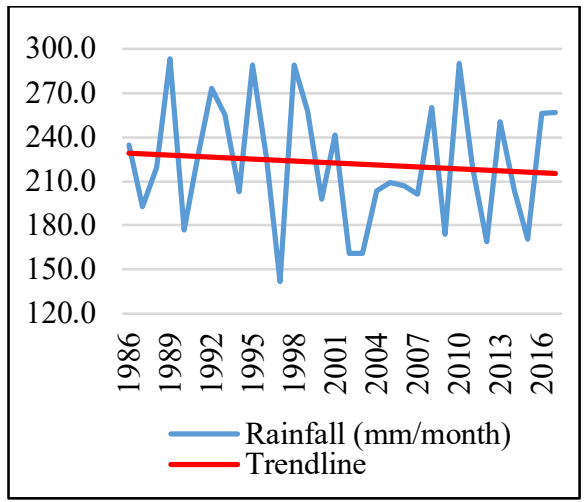

Fig. 2. The average rainfallof Cirebon Regency in 1986-2017

Source: Jatiwangi Meteorological Station, 1986-2017

\subsection{Rainfall Projection Trend}

Climate variability projection is needed to identify climate pattern in the future. The rainfall projection in this study is based on the Representative Concentration Pathways (RCP) scenario, in particular RCP 4.5 that indicates future conditions with moderate emission reduction policies or similar to B1 on SRES. A common problem with GCM data for regional or local climate risk assessment is the low horizontal grid resolution and rainfall estimates vary greatly, especially in the tropics. Moreover, GCM output data does not follow local historical climate variability observational data as a baseline. In this study, GCM simulation results for average monthly rainfall amounts show relatively close to observation data, while the annual rainfall pattern in Figure 3 varies greatly with baseline condition.

Rainfall from GCM projection of Cirebon Regency in the period of 2020-2045 tends to decrease in April-September and increase in October-March. The lowest rainfall was in September and the highest rainfall was in January. The average annual rainfall in the projection period is $2.611 .62 \mathrm{~mm} /$ year and the monthly average rainfall is 217.63 $\mathrm{mm} / \mathrm{month}$. Thus, the GCM output data shows relatively declining rainfall trends fromthe baseline period. Based on the projection results, the highest rainfall occurred in 2027 with an average rainfall of $241.14 \mathrm{~mm} / \mathrm{month}$, while the lowest rainfall occurred in 2038 with an average rainfall of $189.77 \mathrm{~mm} / \mathrm{month}$.

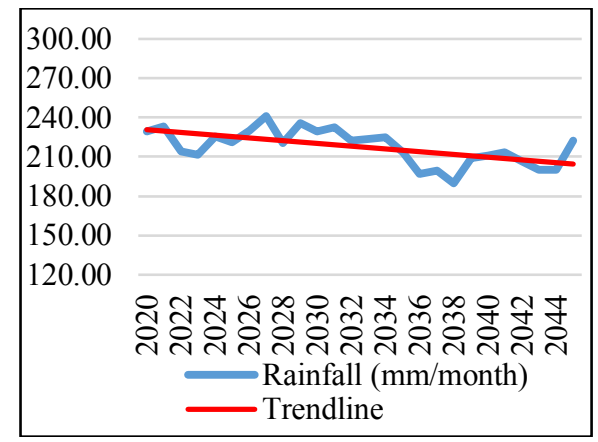

Fig. 3. The average rain fall projection of Cirebon Regency in 2020-2045

Source: Global Circulation Model 


\subsection{Historical and Projection of Dry Months Period}

According to WMO, 3-month SPI is more effective in highlighting the humidity conditions in agricultural areas [17].3-month SPI provides a comparison of precipitation over a specified 3-month period with a total rainfall of the same 3-month period for all years included in long-term historical data. We used 3-month SPIfor this analysis and divide itbased onthe planting period in the study area that are October-March and AprilSeptember. Thus, the quarterly SPI analysis is divided into January-February-March (JFM), April-May-June (AMJ), July-August-September (JAS), and October-November-December (OND) with abaseline periodof 1986-2017 and projection period of 2020-2045.

The dry month periodsfor the baseline periodmore often happened in April-June and October-December (see Figure 4.a). Thedrought periods were influenced by El Nino phenomena among othersin 1988, 1991, 1997 and 2015. El Nino that occurred in $1987 / 1988$ and $1991 / 1992$ were strongly categorized, while in 1997/1998 and 2015/2016 were very strong El Nino [2, 3, 5, 19]. The SPI results in the baseline period also show that thedrought periods influenced by climate seasonality for instance in 2000, 2004, 2011 and 2012. Regarding to the first planting period, the pattern of drought periods in OctoberDecember was occurred frequently over the last 15 years whereas in January-March were rarely happened in every decade. The pattern of drought periods in April-June for the second planting period was also occurred oftentimes over the last 15 years and sometimes even going to October-December in the same year. Other studies show that the dynamics of droughts had an increasing frequency, severity and duration during the last five decade [20, 21].Different from other drought periods in the study area, the pattern of drought periods in July-September was only happened when strong or very strong El Nino.

SPI analysis of the rainfall projection data is needed to identify the indication of future drought in Cirebon Regency. The results of 3-month SPI in the projection period of 20202045 in Figure 4.b show the rainfall with moderately dry classification predicted to occur in 2023, 2035, 2036, 2041, 2042, and 2043; severely dry in 2024, 2032, 2037 and 2039; and extremely dry in 2025, 2038 and 2044. If we compare to SPI values in the baseline condition, it can be seen that the drought periodsare very varied and uncertain with increasing severity of drought.

In the first planting period, the drought periods will rarely happen in OctoberDecember, nevertheless, it will repeated about two to five yearsin January-March. In the second planting period, the drought periods in April-June and also July-September are predicted to occur in the next 15-25 years. The SPI results show that the drought periods in July-September are more often happen than the other3-month periods. This condition is different from the baseline period which drought periods more often happened in AprilJune and October-December. Thus, the drought period may experience a shift in the future.

The result of SPI analysis in this projection period can be a reference to regulate the future planting period because it provide information of indication of drought occurrence in the study area. Such climate information may provide evidence of potential risks to climate shocks which may then help to anticipate the cost and scale of required action [22]. Understanding of how climate change and variability affect future drought hazards is essential to determine the appropriate adaptation measures in order to copewiththe impacts. Adaptation options to anticipate crop failures include changing the date of planting of rice crop so as not to be carried out during the dry months, changing the appropriate crop varieties, and crop diversification [22-24]. 

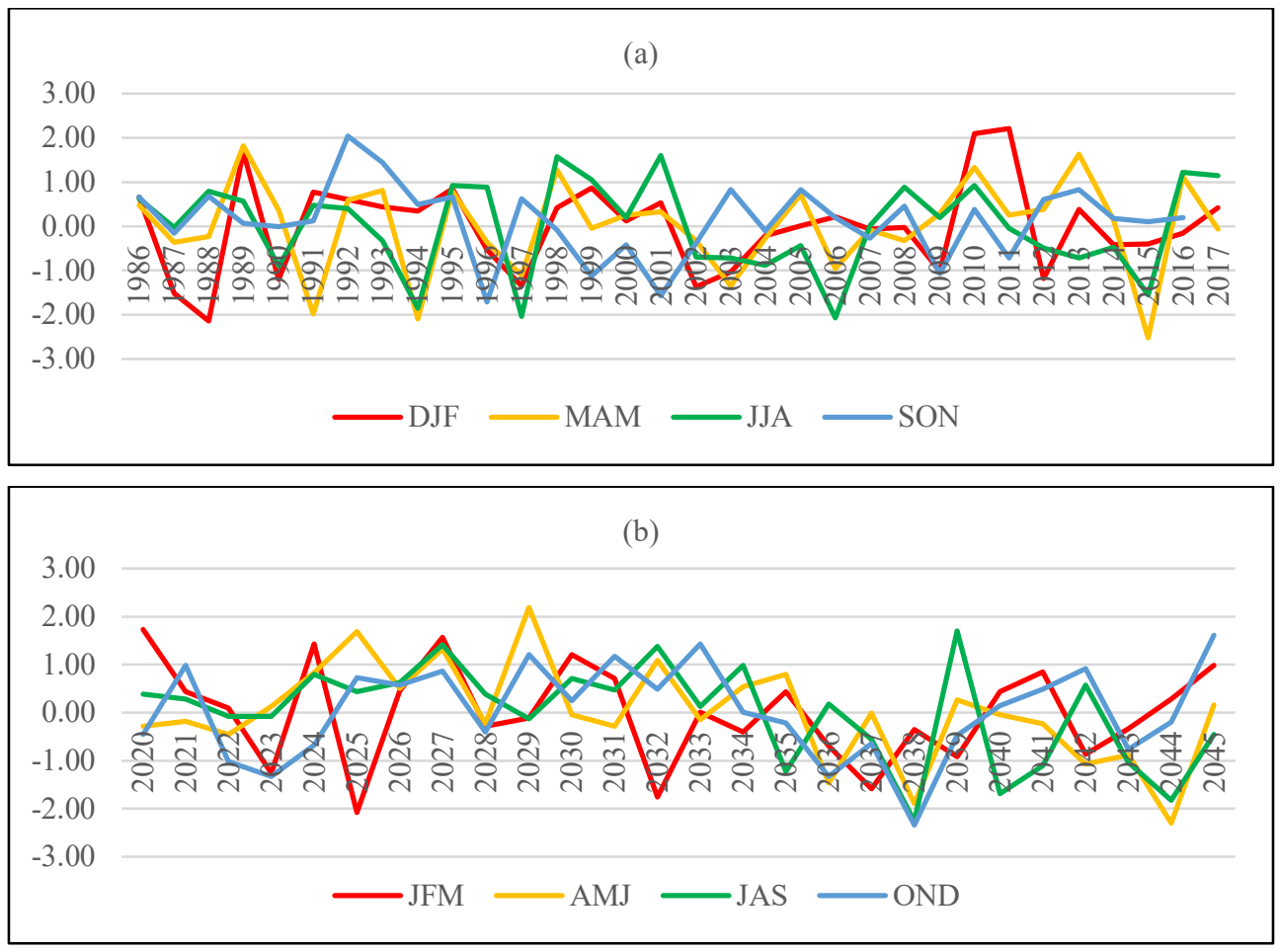

Fig. 4. Three-month SPI in Cirebon Regency

(a)Baseline Periodof 1986-2017; (b) Projection periodof 2020-2045

\section{Conclusions}

This study explains that the climate hazard affects the occurrence of drought andcause impacts on the agricultural sector. Therefore, all stakeholders should have climate literacy, both historical and projection, in order to determine the effective efforts that need to be done to reduce the potential impacts of climate hazard. This study suggests the use of SPI to assess drought periods and its severity. This study concludes that climate variability that affects future dry rainfall will still happen in uncertain month periods with increasing severity. The drought periods projection in the study area may cause hydrological drought and result in the impacts on agricultural production as has happened before. This study only investigates the drought periods trend and projection. Therefore, it is recommended for future study to add a simulation of crop production based on climate projection to know the risk of decreasing crop productivity due to drought.

\section{Acknowledgments}

The authors acknowledge support from Hibah PITTA 2018 that funded by DRPM Universitas Indonesia No.2582/UN2.R3.1/HKP.05.00/2018.

\section{References}

1. IPCC, Climate change (Synthesis report, Geneva, 2014) 
2. UNDP Indonesia, Sisi lain perubahan iklim: Mengapa indonesia harus beradaptasi untuk melindungi rakyat miskinnya (Jakarta, UNDP Indonesia Country Office, 2007)

3. Bhuvaneswari, K., Geethalakshmi, V., Lakshmanan, A., Srinivasan, R., \& Sekhar, N. U. Weather and Climate Extremes 2 (2013)

4. Capa-Morocho, M., Rodríguez-Fonseca, B. \& Ruiz-Ramos, M. Agricultural and Forest Meteorology (2014)

5. Irawan, B. Jurnal Forum Penelitian Agro Ekonomi 24, 1 (2006)

6. Dai, A. Wiley Interdisciplinary Reviews: Climate Change 2, 1 (2011)

7. Chang, K., Xu, L., Starr, G., \& U, K. T. P. Agricultural and Forest Meteorology 250251 (2018)

8. Wilhite, D. A, Chapter 1 drought as a natural hazard: concepts and definitions (London, Routledge, 2000)

9. Wilhite, D. A., \& Glantz, M. H. Understanding the drought phenomenon: The role of definitions (Water International, 1985)

10. Mishra, A. K., \& Singh, V. P. Journal of Hidrology 391 (2010)

11. KLHK. SIDIK: sistem informasi data indeks kerentanan. (Jakarta, Kementerian Lingkungan Hidup dan Kehutanan, 2017)

12. Pratiwi, N. A. H., Rahmawati, Y. D., \& Setiono, I. Asian Cities Climate Resilience Working Paper Series 39 (2016)

13. Kabar Cirebon. Dampak kekeringan kian parah (2016)

14. Khayyati, M., \& Aazami, M. Ecological Indicators 69 (2016)

15. Mohammed, R., \& Scholz, M. Journal of Arid Environments 144 (2017)

16. McKee, T. B., Doesken, N. J., \& Kleist, J. The relationship of drought frequencyand duration to time scales. 8th Conference on Applied Climatology, Anaheim, California, January (1993)

17. WMO. Standardized precipitation index user guide. (Geneva, World Meteorological Organization, 2012)

18. WMO. WMO statement on the status of the global climate in 2014. (Geneva, World Meteorological Organization, 2014)

19. NOAA. .2015. El Nino Impacts and Southeast Region Outlook November 2015 (2018)

20. Byakatonda, J., Parida, B. P., \& Kenabatho, P. K. Physics and Chemistry of the Earth 105 (2018)

21. Oliveira-Júnior, J. F., Gois, G., Terassi, P. M. B., Junior, C. A. S., Blanco, C. J. C., Sobral, B. S.,\&Gasparinih, K. A. C. Atmospheric Research 212 (2018)

22. Shiferaw, B., Tesfaye K., Kassie, M., Abate, T., Prasanna, B. M., \& Menkir, A. Weather and Climate Extremes 3 (2014)

23. Abid, M., Schneider, U. A., \& Scheffran, J. Journal of Rural Studies 47 (2016)

24. Khanal, U., Wilson, C., Hoang, V., \& Lee, B. Ecological Economics, 144 (2018) 